\title{
Stable platform and dynamic oceanic palaeogeography
}

\author{
ARTHUR J. BOUCOT
}

Tropical-subtropical fossils (certain fusuline foraminifera, certain radiolaria, certain bivalves, certain corals) of Permian and Jurassic age now occur in Northern Pacific Asian and North American marginal areas. Their presence indicates original locations in tropical-subtropical, warm water "central" Panthalassa from which they were transported and accreted to cooler water areas. This information, palaeontological and lithological is the basis for the conclusions made here. - Key words: Permian oceanic palaeogeography, post-Permian movements from mid-Panthalassa sources, bedded oceanic chert records.

BouCOT, A.J. 2015. Stable platform and dynamic oceanic palaeogeography. Bulletin of Geosciences 90(1), 133-143 (1 figure). Czech Geological Survey, Prague. ISSN 1214-119. Manuscript received July 17, 2014; accepted in revised form November 15, 2014; published online January 8, 2015; issued January 26, 2015.

Arthur J. Boucot, Department of Zoology, Oregon State University, Corvallis, Oregon 97331, U.S.A.; boucota@science.oregonstate.edu

There are two basic palaeogeographic types. The first with which we are familiar is the stable platform, the "continental" type. The second, is the dynamic oceanic. Palaeogeography deals largely with the stable platform. On the stable platform one may plot lithofacies data, lithofacies data with climatic zone implications, reef environments and many other classes of geologic-palaeontologic information. From the combined similarities and differences provided by data from various platforms, Cambrian to Neogene one may arrive at reasonable palaeogeographies (Boucot et al. 2013). The stable platform data is commonly combined with the data of remanent magnetic information to arrive at more precise latitudinal solutions. One caveat, warning, here is that the remanent magnetic data should reflect the same time interval derived from the palaeontologic information provided by each stable platform. Remanent magnetic data that has been "reset" by significantly younger heating events can lead to erroneous latitudinal conclusions.

Phanerozoic palaeographic analysis is a complex business. Ideally it involves the following: as small time slices as possible, largely based on the available fossil record; careful animal community analysis aimed at distinguishing shallow water, shoreline region, and deeper water environments; recognition of nonmarine facies and associated nonmarine fossils whenever possible in order to more reliably locate the shoreline region; climatic analysis based on using the distribution of climatically sensitive lithologic types such as evaporites, calcretes, lateritic types including bauxites, coals, clay minerals with climatic significance such as kaolin, corrensite and smectite plus the poleward distributions of climatically sensitive animals and plants such as palms, mangroves and crocodilians that enable the recognition of global climatic belts.

The stable platform, underlain by basement complex, commonly features dominant, widespread carbonate rocks in shallower water regions, fringed by fine-grained siliciclastics in deeper water regions, with faunas adapted to those different environments. The stable platforms present in cool to cold regions lack widespread, abundant carbonate rocks in shallower water regions, as well as evaporites and organic reefs, as contrasted with widespread siliciclastic rocks, with cool to cold water, lower diversity faunas.

It is important to recognize that the ever changing global climatic gradient, high to low, exerts a primary control over whether cool to cold water marine strata will be deposited at high latitudes.

The dynamic oceanic regions feature an underlying ophiolitic complex capped by bedded radiolarian cherts that may include conodonts in strata of appropriate age, with an absence of shelly fauna, and characteristically lacks abundant siliciclastic strata including detrital quartz. The dynamic oceanic may also include shallow water carbonate rocks that represent oceanic islands built on a volcanic basement, as well as shallow water carbonate rocks that represent spreading center islands.

Between the stable platform and the dynamic oceanic there is a transitional, bathyal and near platform oceanic region. The bedded radiolarian cherts of this transitional region are commonly much thicker than those of the adjacent oceanic, may include substantial, interbedded siliciclastic detrital material ultimately derived from the 
adjacent platform. The seminal paper making clear the changing character and thicknesses involved as an oceanic sedimentary unit approaches the continent is provided by Matsuda \& Isozaki (1991).

\section{Rewiew of palaeogeographic data}

\section{Permian examples}

\section{Dynamic oceans}

Little attention has been paid to the palaeogeography of the oceanic realm through time, including the locations of ancient spreading centers and oceanic islands. Exceptions include the attention given to Carboniferous to Cretaceous oceanic bedded radiolarian cherts, plus evidence of oceanic islands suggested by certain shelly limestones, in marginal areas of eastern Asia from the Koryak Mountains, north of Kamchatka, south through the Khabarovsk area, Sikhote Alin, northeastern Heilongjiang, Japan including the Ryukyus, to the Palawan area of the Philippines. In western North America there is similar evidence from the Peninsular area of south-central Alaska, the southern Yukon and British Columbia to eastern Oregon and a few California localities. The evidence consists chiefly of bedded radiolarian cherts of oceanic type, some with associated limestones concluded to have been derived from oceanic islands for the most part. Neither the bedded cherts nor the limestones are commonly associated with ophiolitic basement owing to later tectonic dismemberment, although the limestones may rest on volcanic basement in some cases. The limestones contain shallow water shelly marine faunas with biogeographic affinities in some cases to those present on the stable platforms. The Japanese examples are the most extensively investigated, and the oceanic interpretation for the others rest largely on their overall similarity to the Japanese examples.

Establishing the latitudinal position of these ocean derived materials depends on the following reasoning. If one extends the warm/hot, tropical-subtropical climatic zones established on the stable platforms, following the Boucot et al. (2013) compilation across the oceans, Panthalassa in particular, one can then conclude that the platform marginal Tethyan faunas of the Permian and Jurassic were derived from the Permian and Mesozoic tropical-subtropical belt and then transported northeasterly to collide and become part of western North America, or were transported northwesterly to become part of eastern Asia, or were transported southwesterly to become part of North Island, New Zealand. Shi (2006) termed the Tethyan type Permian faunas of eastern Asia the Panthalassan Province. This biogeographic term could also be applied to the Tethyan type faunas in marginal parts of western North America.
Those eastern Asian, marginal, Tethyan faunas presumably originating from spreading centers and oceanic islands in the western parts of "central" Panthalassa may be contrasted with their opposite numbers in marginal parts of western North America from Alaska on the north, south into Central California. The presence in North Island New Zealand of similar oceanic strata including warm water, Permian Tethyan bedded cherts and Lower Jurassic cooler water bedded cherts suggests a southwesterly movement from Panthalassic Southern Hemisphere spreading centers, beginning with Tethyan radiolarians in the Permian extending into cooler water, higher latitude Jurassic cherts. The absence of such data for western South America may reflect an absence of adequate geologic activity plus a lack of palaeontologic effort rather than a basic absence.

Wakita \& Metcalfe (2005) summarized the seafloor spreading origins of East Asian oceanic type units with their potential histories from origins at spreading centers to their present continent marginal positions. Kojima \& Kametaka (2000) provided an overview of Late Palaeozoic to Jurassic and Cretaceous oceanic type occurrences at varied locales in eastern Asia, with useful index maps for specific areas. Tikhomirova (1988) summarized information about Far Eastern Russian Jurassic oceanic type radiolarians. Mizutani \& Kojima (1992) summarized the relation of Japanese units to those as far North as the Khabarovsk area, with radiolarian descriptive material which implies that both areas include Tethyan radiolaria.

Tilman et al. (1982) provided an overview of the tectonic complexities of the Kamchatkan Koryak area. Sokolov (1990) made clear the structural complexities of the Koryak Highlands, as did Vishnevskaya \& Filatova (1994)!

Permian fusulines, corals and bivalves. - Kobayashi (1999) reviewed the Late Permian, Lopingian, emphasizing the Palaeofusulina-bearing localities of the circum-Pacific Tethyan faunas with their palaeobiogeographic implications.

Mizutani et al. (1990) while reviewing the Triassic and Jurassic radiolarian bearing strata from the Nadanhada area southerly to Palawan and Borneo, also indicated (fig. 3, and accompanying text) associated occurrences of PermoCarboniferous fusulines, Tethyan in type. Isozaki \& Aljinović (2009, table 1) summarized the stratigraphic record of the Alatoconchidae in the Permian, including Japanese, Palawan, Malaysian and Thai occurrences.

Koryak area. - Davydov et al. (1996) described Permian fusulinids of Tethyan type from the Koryak area of northeastern Russia, associated with Tethyan waagenophyllid corals (Kachanov 1984); this is the northernmost Old World Tethyan material of tropical-subtropical type that was derived by northerly movement from an original position far to the South in a tropical-subtropical part of Panthalassa. 
Primorye area. - Chedija (1981) reported Midian Lepidolina, a Tethyan taxon, from southern Primorye.

Sikhhote-Alin area. - Sosnina (1960) cited Tethyan fusulinids from Sikhote-Alin.

Nadanhada Range, Northeast China. - Han Jian-xiu (1985) described Permian Tethyan fusulines from the Nadanhada Range. Mizutani et al. (1990, fig. 3) noted the occurrences of Tethyan fusulines in the Nadanhada area south to Palawan.

Japan. - Kasuya et al. (2012) made a strong case for the Early and Middle Permian, Tethyan, Panthalassan occurrence of Yabeina occurrences followed by uppermost Lepidolina occurrences, while suggesting that biogeographically Yabeina occurs at lower tropical latitudes than Lepidolina. This paper summarized the extensive Japanese occurrences of Tethyan fusulines and their palaeogeographic distribution and origins. Kirschvink \& Isozaki (2007) provided a $12^{\circ} \mathrm{S}$ latitude for the southernmost samples.

Ota \& Isozaki (2006) discussed the end Guadalupian extinction of the larger fusulines, especially the Tethyan forms using evidence from the Kamura, Kyushu, and Akasaka, Honshu areas that are thought to represent seamounts, with Kasuya et al. (2012) providing more detailed information about the Kamura area.

Mizutani et al. (1990) cited Tethyan fusulines and Waagenophyllum from the Ryukyu arc. Isozaki (2006) described a Guadalupian alatoconchid occurrence from Kyushu in a "mid-Panthalassian paleo-atoll complex" with associated, well-dated fusulines.

Thailand. - Udchachon et al. (2014) described or cited alatoconchids, Waagenophyllum and Tethyan fusulines from the Loei area of the Indochina Terrane in eastern Thailand.

Palawan area. - Amiscaray (1987) discussed Tethyan fusulines from northwestern Palawan.

Sarawak. - Sanderson (1966) listed some earlier Permian fusulines from southern Sarawak, but no typical Tethyan forms were noted.

New Zealand. - Aita \& Spörli (2007, fig. 2; see also Spörli $\&$ Gregory 1980, who early recognized the major transoceanic transport suffered by these fossils) noted Tethyan fusulines from the Northland, New Zealand Waipapa area, while Leven \& Grant-Mackie (1997) described a typical Middle Permian Tethyan fusuline fauna from Wherowhero Point, Orua Bay, Northland.

Westernmost North America. - Belasky \& Stevens (2006) reviewed the Permian faunas of the westernmost North American Cordillera.
Alaska. - On the Kenai Peninsula, Kodiak Island and Anchorage areas, Alaska, ophiolitic mélange produced Tethyan fusulines (Stevens et al. 1997), while from the same area Blodgett \& Isozaki (2013) discussed the presence of an alatoconchid, a giant Tethyan bivalve.

British Columbia. - Orchard \& Danner (1991) reviewed the palaeontology of the Cache Creek belt.

Orchard et al. (2001) reviewed the Tethyan Permian fauna, including fusulines, Waagenophyllum and the Tethyan alatoconchid bivalve Shikamaia from the Cache Creek belt of central British Columbia.

Cordey \& Schiarizza (1993) described the Cache Creek type rocks and Tethyan fusuline fauna of the Bridge River complex of southwestern British Columbia.

Kobayashi et al. (2007; see also Gota et al. 1986) described Late Guadalupian fusulines featuring Yabeina from the Cache Creek Group of southern British Columbia in the Marble Canyon-Hat Creek area.

Oregon, Northwestern Washington and Southeastern British Columbia. - Bostwick \& Nestell (1967) discussed Tethyan fusulinds from eastern Oregon, southwestern British Columbia and northwestern Washington, all presumably derived from warm water, tropical-subtropical areas. Nestell \& Stevens (2013) described an Upper Triassic conglomerate from Central Oregon that contains clasts yielding Carboniferous and Permian corals and fusulines of McCloud Belt type with others yielding typical Tethyan corals and fusulines, suggesting that by at least the Upper Triassic the marginal Laurentian McCloud Belt and the source of the Tethyan fossils were very close together and might even have already joined with Laurentia.

Central California. - Douglass (1967) described Tethyan fusulines from west-central California, their southernmost in situ occurrence, from the Calaveras Formation near Jackson, which raises the possibility that the Calaveras Formation (see Duffield \& Sharp 1975, for a discussion of the Calaveras Formation) is a Tethyan derived area, possibly related to the Cache Creek belt. Douglass (1967) stated that Bostwick and Nestell mentioned to him that in Oregon they had identified Nagatoella and Misellina, two Tethyan genera. Still further south in California Stevens (1977, fig. 5, loc. 16) cited Middle Permian Tethyan fusulines (Stevens, written comm., 2011, generously provided the following unpublished information about this southernmost North American Tethyan locality: "Middle Permian, definitely Tethyan, extracted from a pebble in a conglomerate in what was referred to as the Calaveras complex in Yokohl Valley about $25 \mathrm{~km}$ northeast of Porterville, CA. The collection was made by Jason Saleeby and the fusulinids were studied by me. The fusulinids I identified as Yabeina? I question the identification 
because in the very limited material I had I was unable to get well-oriented sections.").

\section{Late Palaeozoic and Mesozoic radiolaria}

There is a basic difference in the Baumgartner (1987) vs Pessagno (many references) view of just what controlled Mesozoic radiolarian distributions, with Pessagno opting for latitudinally correlated biogeographic differences, while Baumgartner preferred to interpret their distribution patterns as due to oceanographic factors. I opt for Pessagno's view owing to the good fit between the data derived from western North America, far north to south, that agrees so well with the biogeographic model, plus the Kiessling \& Scasso (1996) information from the Antarctic Peninsula. Baumgartner's view appears to have been influenced by the largely Tethyan nature of the bulk of his materials, i.e., not nearly as much north-south latitudinally correlated information.

Kamchatka, and the Koryak Mountains. - Vishnevskaya (1994) described some Permian radiolarians from the Koryak Highlands.

Vishnevskaya (1992) described Jurassic and Cretaceous radiolarians from the Koryak Upland. Vishnevskaya \& Filatova (1994) discussed Tethyan Jurassic radiolarians from some Koryak Mountains localities. Sey \& Kalaheva (1983) described Late Jurassic Tethyan ammonites in units of the Koryak area and other high northern latitude localities. Vishnevskaya et al. (1991) described Jurassic Tethyan radiolarians from the Koryak area.

Khabarovsk area. - Zyabrev \& Matsuoka (1999) summarized information from the Khabarovsk complex of Far Eastern Russia, making it clear that Late Jurassic bedded radiolarian cherts and siliciclastic units indicate a continental approach of an oceanic unit; no ophiolites are associated, presumably owing to structural dismemberment of an oceanic unit. Suzuki et al. (2005) described Permian radiolaria from the Khabarovsk area. Kojima et al. (1991) discussed and illustrated some Triassic and Jurassic radiolarians from the Khabarovsk area.

Sikhote-Alin area. - Kojima et al. (2000) summarized the relations of the southern Sikhote-Alin area to a similar Japanese unit. Kojima (1989) provided additional data for the Sikhote-Alin, Nadanhada and Japanese areas, while pointing out the similarity of the Mino and Nadanhada radiolarians.

Kemkin \& Khanchuk (1994) discussed and described some Jurassic radiolarians from southern Sikhote-Alin.

Nadanhada area, Northeastern China. - Mizutani et al. (1986) described rock types and illustrated some Triassic and Jurassic radiolaria from the Nadanhada area of Northeastern China. Kojima \& Mizutani (1987) added additional information, which Kojima (1989) for the Jurassic interpreted as Southern Boreal Province in the Jurassic, with the Japanese Mino area being Tethyan. Zhang (1990) described Late Triassic to Middle Jurassic radiolaria from the Nadanhada Range. Yang \& Mizutani (1991) stressed the overall similarity of the Triassic and Jurassic in the Mino and Nadanhada areas and suggested that they were formerly parts of the same unit. Yeh \& Yang (2006) described Late Triassic and Early Jurassic radiolaria from the Nadanhada area, which seem similar to those from the Queen Charlottes and the Mino area; this similarity would imply a Tethyan biogeographic assignment. Mizutani et al. (1990) summarized the data on the presence of Triassic and Jurassic radiolaria in the Nadanhada area.

Honshu, Japan. - Wakita et al. (2001) discussed the characteristics of the Mino and Hida areas on Honshu in some detail. Yao (1983) reviewed Permian through Cretaceous radiolarian occurrences from Honshu. Yao et al. (1980) and Yao (1982) described Triassic and Jurassic radiolaria from the Inuyama area, Mino Belt, central Japan. Isozaki \& Matsuda (1985) described Early Jurassic radiolarians from Kamiso in the Mino Belt, with references to many varied ancillary papers on Triassic and Jurassic Mino area radiolarians. Hori (1990) dealt with Lower Jurassic radiolarians from southwestern Japan. Mizutani \& Kido (1983) described some Middle Jurassic radiolarian from the Mino area. Kishida \& Hisada (1985) described Late Triassic to Early Jurassic radiolarians from the Kanto Mountains central Japanese Mino area, with a Tethyan Province implication.

Ryukyu Islands. - Ujie \& Oba (1991) discussed the Ryukyu Island locations and illustrated Permo-Jurassic radiolarians.

North Palawan Block. - The North Palawan Block [Isozaki et al. 1988; Faure \& Ishida 1990; Tumanda 1991; Cheng 1989 (Permian and Triassic), 1992 (Tethyan Tithonian); Kiessling \& Flügel 2000; Zamoras \& Matsuoka 2000, 2001] is a very complex set of Late Pennsylvanian (Moscovian) through later Jurassic bedded radiolarian chert "units" mixed with varied shallow water limestones yielding Tethyan fusulinid Permian faunas. The bedded radiolarian cherts are most easily interpreted as oceanic strata, whereas the shallow water, shelly limestones are interpreted as oceanic island remnants; none of these structurally complex items is related to ophiolites, with subsequent structural processes assumed to have been responsible for the absence. Cheng (1992) concluded that the Jurassic radiolarians are Tethyan types.

Indonesia. - Scattered occurrences of Jurassic and Cretaceous mélange yielding bedded radiolarian cherts, as well 


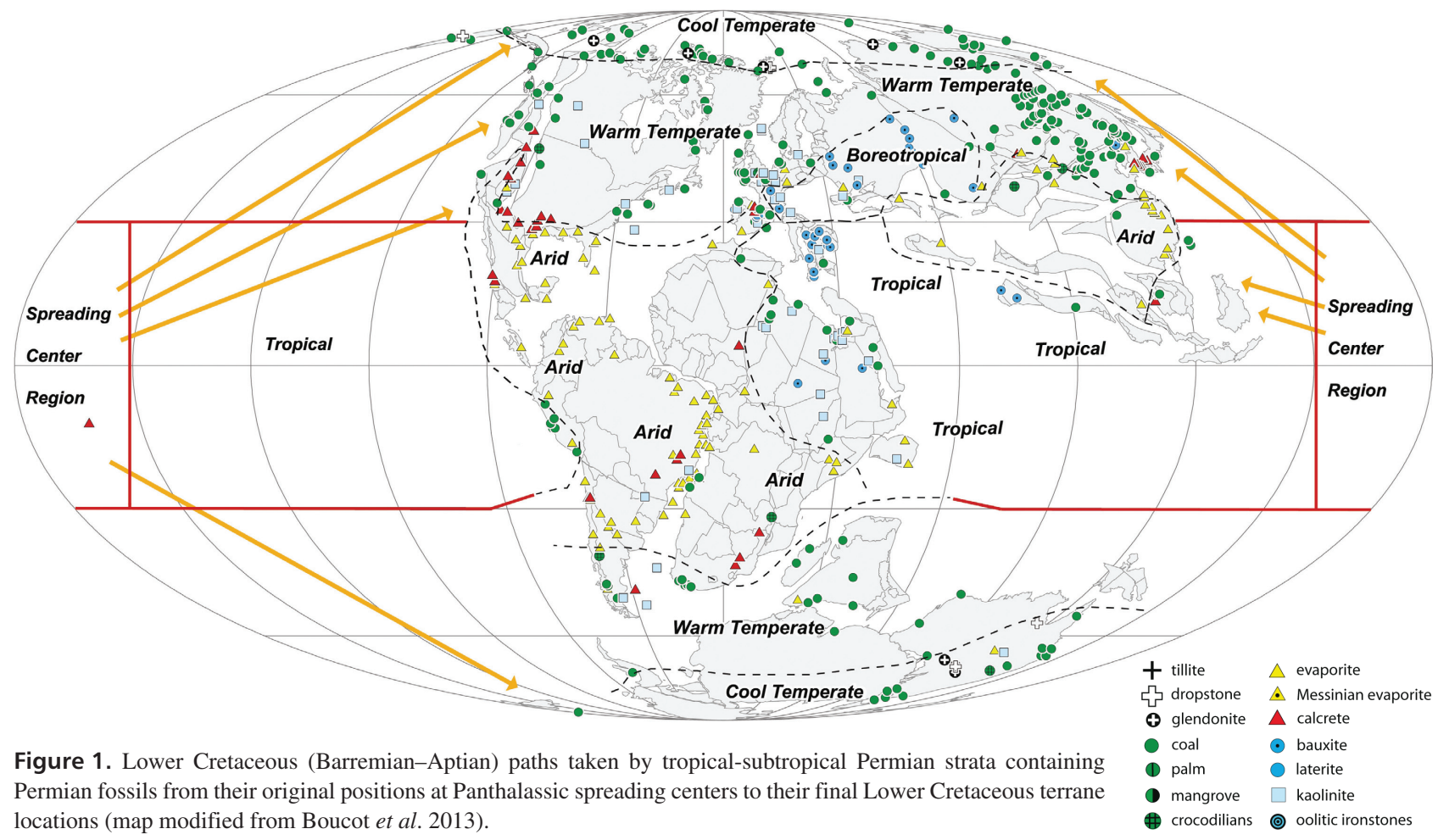

as limestones, basalt and ophiolitic rock types occur in the Lok Ula Complex on Java, the Meratus Complex on Kalimantan and the Bantimala Complex on Sulawesi (Wakita 2000; Wakita et al. 1998, 1994). Pessagno \& Hull (2002) described Northern Austral Province Oxfordian radiolarians from the Sula Islands, close to eastern Sulawesi. Tan (1978) discussed Lower Cretaceous radiolarian cherts from the Lupar Valley of West Sarawak, while Leong (1975) discussed a chert-spilite association from the Lower Cretaceous of Sabah. McCarthy et al. (2001) described Middle Jurassic radiolarian cherts from western Sumatra.

The "original" positions of these Indonesian oceanic type units is still uncertain as to whether they represent Panthalassic oceanic remnants or alternatively had origins from an oceanic area south of present day Indonesia.

New Zealand. - Spörli et al. (2007a; see also Spörli \& Aita 1988, Spörli et al. 2007b) described the Middle Permian to Middle Triassic radiolarian cherts from northernmost North Island, New Zealand, featuring warm water Permian and cool water younger fauna (Aita \& Spörli 2007, fig. 2, refer to the Permian and earlier Triassic faunas as Tethyan). Adachi et al. (1986) discussed Permian radiolarian cherts from North Island, New Zealand. Spörli et al. (1989) discussed some Tethyan and non-Tethyan, Southern Hemisphere radiolarian faunas from the Waipapa area, North Island, New Zealand. Aita \& Grant-Mackie (1992) described Late Jurassic radiolaria from the Murihiku area, North Island suggesting that that they represent Southern Hemi- sphere equivalents of the Northern Tethyan and Southern Boreal Provinces, i.e., a relatively warm water fauna, as contrasted with the colder water Arrow Rocks Waipapa area faunas.

Westernmost North America. - Damborenea \& Manceñido (1979) noted the Lower Jurassic occurrence of the warm water, low latitude, western Americas, North and South, Early Jurassic bivalve genus Weyla in the Kuskokwim, Wrangellia, the northern Yukon (Laberge Group), and the Tyaughton Group, plus Nilkitwa, Telkwa, Ntlakapamax formations and the Ladner Group, as well as on Vancouver Island, the Queen Charlotte Islands, the Blue Mountains of eastern Oregon, the Taylorsville District of California, Hardgrave and Lilac formations, and the Potem Formation of Shasta County.

Blodgett (2009) described the presence of Weyla in the Lower Jurassic of the Cook Inlet Basin part of the Alaskan Peninsular area. Aberhan (1999; see also Aberhan \& Muster 1997, and Aberhan 1998, for additional Early Jurassic bivalve evidence) made it clear that Early Jurassic pectinoid evidence, including Weyla, indicates, that both Wrangellia and Stikinia underwent major northerly movement from original tropical-subtropical positions to their present far northerly positions, with evidence from as far north as parts of Alaska to the north of the latitude of the present northern Yukon; he also summarized earlier Jurassic ammonite evidence from the same areas that arrived at similar latitudinal conclusions. 
The occurrence of Famennian, later Late Devonian age strata above the ophiolitic rocks of the Chulitna area (Jones et al. 1980) in south-central Alaska, the northernmost occurrence of the Wrangellia area, raises the possibility that this Tethyan sourced area began to accumulate in the tropical-subtropical areas of Panthalassa during the later Late Devonian before being transported to accrete with western North America by the Late Jurassic to Early Cretaceous.

Scholz et al. (2008) made it clear that the Early Jurassic bivalves from Sonora, NW Mexico are similar to those of northern Chile, another lower latitude warm water fauna that also has similarities to the Wrangellia and Stikinia faunas.

Central Oregon, Central California, Queen Charlotte Islands. - Pessagno \& Blome (1986) discussed and described the Mesozoic rocks and fossils of the central and eastern Oregon Blue Mountain Province, emphasizing the tropical presence of Weyla in the Lower Jurassic and of a change near the Bajocian-Callovian boundary from earlier Tethyan radiolarian faunas to Boreal type faunas. Pessagno \& Whalen (1982) dealt with some of the Lower and Middle Jurassic radiolaria from east-central Oregon, the Great Valley in California and the Queen Charlotte Islands with Tethyan types indicated for the Lower Jurassic. Carter et al. (1988) described the Tethyan Lower and Middle Jurassic radiolaria of the Queen Charlotte Islands, associated with Tethyan ammonites and foraminifera, and suggested affinity with Wrangellia.

Cache Creek area, British Columbia. - Cordey et al. (1987) reviewed the significance of the Jurassic radiolarians from the Cache Creek area of British Columbia, while indicating that a Serpukhovian to Pliensbachian age is involved overall for the Cache Creek in this area. Cordey (1986) listed Early Permian to Late Triassic radiolaria from the southern part of the Cache Creek Complex in Southern British Columbia and Middle Triassic to Early Jurassic from the nearby Bridge Creek Complex. Cordey et al. (1991) reviewed biostratigraphic data from the Cache Creek area in the southern Yukon. and mentioned Pliensbachian-Toarcian radiolarians Cordey (1998) described radiolarians from the Cache Creek, Bridge River and Hozameen areas.

Caribbean area. - Montgomery \& Pessagno (1994) discussed the varied Tethyan bedded red radiolarian chert fragments of eastern Pacific oceanic origin embedded in the Caribbean area, including La Désirade, Puerto Rico and Hispaniola. They considered the La Désirade red cherts to belong to the North Tethyan Province. Montgomery et al. (1992) considered that the La Désirade Tithonian belongs to the North Tethyan to South Boreal Provinces, i.e., a boundary unit, and considered that the Puerto Rico Jurassic also belongs to the North Tethyan to South Boreal Provinces, i.e., another boundary unit. Montgomery \& Pessagno (1994) concluded that the Hispaniolian Jurassic belongs to the Central Tethyan, and the Puerto Rican Bermejo Jurassic to the Central Tethyan Province.

Eastern Mexico. - Pessagno et al. (1987) assigned the Late Jurassic radiolaria from eastern Mexico to the Northern Tethyan Province. Pessagno \& Martin (2003) summarized the evidence for deriving the Mexican San Pedro del Gallo area from the Southern Boreal Province during the Bathonian and then moving it to the Northern Tethyan Province by the Kimmeridgian and Tithonian and to the Central Tethyan Province by the Early Cretaceous.

Although not involving the movements of oceanic strata to become areas attached to platforms at varied latitudes, Pessagno et al.'s (1999) treatment of northwest to southeast movement of Jurassic rocks from mid-latitude North America to central Mexico and western Cuba is a model for the use of biogeographic information, radiolarians in this case, to explain developing palaeogeographies. They made a strong case that Southern Boreal Province radiolarians $\left(40^{\circ} \mathrm{N}\right)$ bearing strata of Oxfordian (Late Jurassic) age were faulted to the southeast so that by the Tithonian (latest Jurassic) and Berriasian (Early Cretaceous) they were located in Northern Tethyan Province latitudes $\left(22-29^{\circ} \mathrm{N}\right)$, with another part of the unit eventually being faulted easterly to end up in western Cuba. They also included palaeoecologic information indicating a distinct deepening through time from shelf to bathyal or abyssal depths. The starting position of these strata was probably somewhere in east-central California to the west of shallow neritic Late Jurassic strata such as the Sunrise Formation of west-central Nevada (Muller \& Ferguson 1939) and east of the bathyal, turbiditic strata of the Mariposa Slate (Imlay 1952).

California Coast Range. - Pessagno et al. (1986) considered the Jurassic radiolaria to belong to the Southern Boreal Province.

Baja California. - Pessagno et al. (1979) and Whalen \& Carter (2002) dealt with radiolaria from the Late Triassic of the San Hipólito Formation, Baja California, while Whalen \& Pessagno (1984) dealt with the Tethyan radiolaria of this formation.

Costa Rico. - Gursky\& Schmidt-Effing (1983) discussed Late Jurassic-Early Cretaceous, with radiolarian chert, from the Costa Rican Nicoya Ophiolite Complex.

Antarctic Peninsula. - Kiessling (1999; see also Kiessling \& Scasso 1996) described Late Jurassic radiolarians from the Antarctic Peninsula, and concluded that they represent a Southern Hemisphere Austral Province that is equivalent 
to the Northern Hemisphere Northern Tethys and Southern Boreal Provinces.

\section{Synthesis}

Figure 1 (Base map after Boucot et al. 2013, Map 21) provides a visual synthesis of the possible location(s) in "Central Panthalassa's" tropical-subtropical zone of the accreted Permian occurrences now present in the Northern Hemisphere of Eastern Asia and western North America as well as their Southern Hemisphere presence in the accreted Permian of New Zealand. These possibilities were previously considered in large part by Yancey (1976) on a modern base map, and by Ross (1995) on a "mobilist" base map (Ross's reconstruction did not recognize that the Alexander area was derived from far northern rather than tropical-subtropical latitudes [Blodgett et al. 2010], nor did it indicate the potential locations of the East Asian Koryak, Nadanhada or Palawan accreted Tethyan areas among others).

The present map reconstruction takes advantage of the available climatic data that provides a latitudinal constraint for the tropical-subtropical zone if one accepts the assumption that the continental data can be extrapolated across the broad Panthalassan Ocean. Keep in mind that whether or not more than one mid-Panthalassan spreading center was present during the Permian is unknown or just where varied Tethyan oceanic islands might have been situated is also unknown.

\section{References}

Aberhan, M. 1998. Paleobiogeographic patterns of pectinoid bivalves and the Early Jurassic tectonic evolution of western Canadian terranes. Palaios 13, 129-148.

DOI 10.2307/3515485

ABERHAN, M. 1999. Terrane history of the Canadian Cordillera: estimating amounts of latitudinal displacement and rotation of Wrangellia and Stikinia. Geological Magazine 136, 481-492. DOI 10.1017/S001675689900299X

Aberhan, M. \& Muster, H. 1997. Palaeobiology of Early Jurassic bakevellid bivalves from western Canada. Palaeontology 40, 799-818.

Adachi, M., Yamamogto, K. \& Sugisaki, R. 1986. Depositional environment of Permian chert from North Island, New Zealand. Sediments Down-Under, $12^{\text {th }}$ International Sedimentological Congress (Canberra), p. 2.

Aita, Y. \& Grant-Mackie, J.A. 1992. Late Jurassic Radiolaria from the Kowhai Point Siltstone, Murihiku Terrane, North Island, New Zealand. 373-382. In IshiZAKI, K. \& SAITo, T. (eds) Centenary of Japanese Micropaleontology. Terra Scientific Publishing Company, Tokyo.

AitA, Y. \& SPÖRLI, K.B. 2007. Geological framework for the pelagic Permian/Triassic oceanic sequence of Arrow Rocks,
Waipapa terrane, Northland, New Zealand. The Oceanic Permian/Triassic boundary sequence at Arrow Rocks (Oruatemanu), Northland, New Zealand. GNS Science Monograph 24, 1-16.

AmisCARAy, E.A. 1987. Permian fusulinids and other microfossils from northwestern Palawan. Report No. 2, IGCP Project 224, Pre-Jurassic Evolution of eastern Asia, 85-104.

Baumgartner, P.O. 1987. Age and genesis of Tethyan Jurassic radiolarites. Eclogae geologicae Helvetiae 80, 831-879.

Belasky, P. \& Stevens, C.H. 2006. Permian faunas of westernmost North America: Paleogeographic constraints on the Permian positions of Cordilleran terranes. Geological Association of Canada Special Paper 46, 71-80.

BLODGETT, R.B. 2009. Report on day trip (5/16/07) to visit Mesozoic rocks exposed in Port Graham and near Seldovia. Division of Geological \& Geophysical Surveys, Preliminary Interpretive Report 2009(8), 109-116.

Blodgett, R.B., Boucot, A.J., Rohr, D.M. \& Pedder, A.E.H. 2010. The Alexander Terrane - a displaced fragment of northeast Russia - Evidence from Silurian-Middle Devonian megafossils and stratigraphy. Memoir of the Association of Australasian Palaeontologists 39, 325-341.

Blodgett, R.B. \& Isozaki, Y. 2013. The Alaticonchidae, giant Permian Tethyan bivalve family, and the first occurrence in Alaska (McHugh Complex of the Chugach Terrane) and the Western Hemisphere. Alaska Geology 43(8), 5-8.

Bostwick, D.A. \& Nestell, M.K. 1967. Permian Tethyan fusulinid faunas of the northwestern United States, 93-102. In Ager, C.G. \& Adams, D.V. (eds) Aspects of Tethyan Biogeography. The Systematics Association, Publication No. 7, London.

Boucot, A.J., Chen, X. \& Scotese, C.R. 2013. Phanerozoic paleoclimate: An atlas of lithologic indicators of climate. 348 pp. SEPM, Tulsa.

Carter, E.S., Cameron, B.E.B. \& Smith, B.L. 1988. Lower and Middle Jurassic radiolarian biostratigraphy and systematic paleontology, Queen Charlotte Islands, British Columbia. Geological Survey of Canada Bulletin 386, 1-109. DOI 10.4095/122711

Chedija, I.O. 1981. On some criteria of Lepidolina species (family Neoschwagerinidae). Voprosy mikropaleontologii 24, 60-75.

Cheng, Y.-N. 1989. Upper Paleozoic and Lower Mesozoic radiolarian assemblages from the Busuanga Islands, North Palawan Block, Philippines. Bulletin of National Museum of Natural Science 1, 129-175.

Cheng, Y.-N. 1992. Upper Jurassic Pantanelliidae (Pantanelliinae Pessagno, 1977 and Vallupinae Pessagno \& Macleod, 1987) from the Busuanga Islands, Philippines. Bulletin of National Museum of Natural Sciences 3, 1-49.

CoRdey, F. 1986. Radiolarian ages from the Cache Creek and Bridge River complexes and from chert pebbles in Cretaceous conglomerates, southwestern British Columbia. Geological Survey of Canada, Current Research, Part A, Geological Survey of Canada, Paper 86-1A, 595-602.

Cordey, F. 1998. Radiolaires des complexes d'accrétion de la Cordillère Canadienne (Columbie-Britannique). Geological Survey of Canada Bulletin 509, 1-209.

Cordey, F., Gordey, S.P. \& Orchard, M.J. 1991. New bio- 
stratigraphic data from the northern Cache Creek terrane, Teslin Map area, southern Yukon. Current Research, Part E, Geological Survey of Canada, Paper 91-1E, 67-76.

Cordey, F., Mortimer, N., DeWever, P. \& Monger, J.W.H. 1987. Significance of Jurassic radiolarians from the Cache Creek terrane, British Columbia. Geology 15, 1151-1154. DOI 10.1130/0091-7613(1987)15<1151:SOJRFT>2.0.CO;2

Cordey, F. \& Schiarizza, P. 1993. Long-lived Panthalassic remnant: the Bridge River accretionary complex, Canadian Cordillera. Geology 21, 263-266.

DOI 10.1130/0091-7613(1993)021<0263:LLPRTB >2.3.CO;2

Danborenea, S.E. \& ManceñIdo, M.O. 1979. On the palaeogeographic distribution of the pectinid genus Weyla (Bivalvia, Lower Jurasssic). Palaeogeography, Palaeoclimatology, Palaeoecology 27, 85-102.

DOI 10.1016/0031-0182(79)90095-6

Davydov, V.I., Belasky, P. \& Karavayeva, N.I. 1996. Permian fusulinids from the Koryak terrane, Northeastern Russia, and their paleobiogeographic affinity. Journal of Foraminiferal Research 26, 213-243. DOI 10.2113/gsjfr.26.3.213

Douglass, R.C. 1967. Permian Tethyan fusulinids from California. U.S. Geological Survey Professional Paper 593-A, A1-A13.

DufFIELD, W.A. \& Sharp, R.V. 1975. Geology of the Sierra Foothills Melange and adjacent areas, Amador County, California. U.S. Geological Survey Professional Paper 827, 1-30.

FAure, M. \& IshidA, K. 1990. The Mid-Upper Jurassic olistostrome of the west Philippines: a distinctive key-marker for the North Palawan block. Journal of Southeast Asian Sciences 4, 61-67. DOI 10.1016/0743-9547(90)90026-A

Gota, H., MaruokA, K. \& Ishi, K. 1986. Lepidolina Columbiana (Permian fusulinid) from British Columbia, Canada. Transactions and Proceedings of the Palaeontological Society of Japan, N.S. 143, 422-434.

GuRsky, H.-J. \& Schmidt-EfFing, R. 1983. Sedimentology of radiolarites within the Nicoya Ophiolite Complex, Costa Rica, Central America, 127-142. In IIJIMA, A., HeIN, J.R. \& SiEver, R. (eds) Developments in Sedimentology 36. Siliceous deposits in the Pacific Region. Elsevier. DOI 10.1016/S0070-4571(08)70088-8

HAN, J.-X. 1985. Early Permian fusulinids from the Nadanhada Range. Acta Palaeontologica Sinica 24, 680-687.

HoRI, R. 1990. Lower Jurassic radiolarian zones of SW Japan. Transactions and Proceedings of the Palaeontological Society of Japan, N.S. 159, 562-586.

ImLAY, R.W. 1952. Correlation of the Jurassic Formations of North America, exclusive of Canada. Geological Society of America Bulletin 63, 963-992.

DOI 10.1130/0016-7606(1952)63[953:COTJFO]2.0.CO;2

IsOZAKI, Y. 2006. Guadalupian (Middle Permian) giant bivalve Alatoconchidae from the mid-Panthalassan paleo-atoll complex in Kyushu, Japan: a unique community associated with Tethyan fusulines and corals. Proceedings of the Japanese Academy, Series B 82, 25-31. DOI 10.2183/pjab.82.25

IsOZAKI, Y. \& ALJinOvić, D. 2009. End-Guadalupian extinction of the Permian gigantic bivalve Alatoconchidae: End of gigantism in tropical seas by cooling. Palaeogeography, Palaeoclimatology, Palaeoecology 284, 11-21.

DOI 10.1016/j.palaeo.2009.08.022
Isozaki, Y., Amiscaray, E.A. \& Rillon, A. 1988. Permian, Triassic and Jurassic bedded radiolarian cherts in North Palawan Block, Philippines: Evidence of late Mesozoic subduction-accretion. International Symposium on the Pre-Jurassic Evolution of Eastern Asia. Report No. 3 of the IGCP project 224, Pre-Jurassic evolution of eastern Asia, 99-115.

IsOZAKI, Y. \& MATSUDA, T. 1985. Early Jurassic radiolarians from bedded chert in Kamiaso, Mino Belt, Central Japan. Earth Science Journal of the Association for Geological Collaboration in Japan 39(6), 429-442.

Jones, D.L., Silberling, N.J., Csejtey, B., JR., Nelson, W.H. \& Blome, C.D. 1980. Age and structural significance of ophiolitic and adjoining rocks in the Upper Chulitna District, South-central Alaska. U.S. Geological Survey Professional Paper 1121-A, 1-21.

Kachanov, Y.I. 1984. A Permian coral (Waagenophyllidae) from the Koryak Highlands. Paleontological Journal 1, 95-98.

KasUYA, A., IsOZAKI, Y. \& IGO, H. 2012. Constraining paleo-latitude of a biogeographic boundary in mid-Panthalassa: Fusuline province shift on the Late Guadalupian (Permian) migrating seamount. Gondwana Research 21, 611-623. DOI 10.1016/j.gr.2011.06.001

Kemkin, I.V. \& KhanchuK, A.I. 1994. Jurassic accretionary prism in the southern Sikhote Alin. Geology of the Pacific Ocean 10(5), 831-846.

KIESSLING, W. 1999. Late Jurassic radiolarians from the Antarctic Peninsula. Micropaleontology 45, Supplement 1, 1-96. DOI $10.2307 / 1486097$

Kiessling, W. \& FlÜGEL, E. 2000. Late Paleozoic and Late Triassic limestones from North Palawan Block (Philippines): Microfacies and paleogeographical implications. Facies 43, 39-78. DOI 10.1007/BF02536984

KiesSLING, W. \& SCASSO, R. 1996. Ecological perspectives on Late Jurassic radiolarian faunas from the Antarctic Peninsula, 317-326. In RiccARDI, A.C. (ed.) Advances in Jurassic Research 1/2. Transtec, Zurich.

KIRSCHVINK, J.L. \& IsOZAKI, Y. 2007. Extending the sensitivity of paleomagnetic techniques: Magnetostratigraphy of weaklymagnetized, organic-rich black limestone from the Permian of Japan. Abstracts, American Geophysical Union Fall meeting (2007), GP 43B-1223, 1-2.

KishidA, Y. \& HisadA, K. 1985. Late Triassic to Early Jurassic Radiolarian Assemblages from the Ueno-mura area, Kanto Mountains, Central Japan. Memoirs of the Osaka Kyoiku University, Ser. III, 34(2), 103-129.

Kobayashi, F. 1999. Tethyan uppermost Permian (Dzhulfian and Dorashamian) foraminiferal faunas and their paleogeographic and tectonic implications. Palaeogeography, Palaeoclimatology, Palaeoecology 150, 279-307. DOI 10.1016/S0031-0182(99)00011-5

Kobayashi, F., Ross, C.A. \& Ross, J.R.P. 2007. Age and generic assignment of Yabeina columbina (Guadalupian Fusulinacea) in southern British Columbia. Journal of Paleontology 81, $238-253$.

DOI 10.1666/0022-3360(2007)81[238:AAGAOY]2.0.CO;2

KoJIMA, S. 1989. Mesozoic terrane accretion in Northeast China, Sikhote-Alin and Japan regions. Palaeogeography, Palaeoclimatology, Palaeoecology 69, 213-232. DOI 10.1016/0031-0182(89)90165-X 
Kojima, S. \& KametaKa, M. 2000. Jurassic accretionary complexes in East Asia. Memoirs of the Geological Society of Japan 55, 61-72.

Kojima, S., Kemkin, I.V., Kametaka, M. \& Ando, A. 2000. A correlation of accretionary complexes of southern SikhoteAlin of Russia and the Inner Zone of Southwest Japan. Geoscience Journal 4(3), 175-185. DOI 10.1007/BF02910136

KoJima, S. \& Mizutani, S. 1987. Triassic and Jurassic Radiolaria from the Nadanhada Range, Northeast China. Transactions and Proceedings of the Palaeontological Society of Japan, N.S. 148, 256-275.

Kojima, S., Wakita, K., OKamura, Y., Natal'in, B.A., Zyabrev, S.V., ZHANG, Q.L. \& SHAO, J.A. 1991. Mesozoic radiolarians from the Khabarovsk complex, eastern USSR: their significance in relation to the Mino terrane, central Japan. Journal of the Geological Society of Japan 97(7), 549-551.

DOI 10.5575/geosoc. 97.549

LEONG, K.M. 1975. New ages from radiolarian cherts of the Chert-Spilite Formation, Sabah. Warta Geologi 1, 96-95.

Leven, E.J. \& Grant-Mackie, J.A. 1997. Permian fusulinid Foraminifera from Wherowhero Point, Orua Bay, Northland, New Zealand. New Zealand Journal of Geology and Geophysics 40, 473-486. DOI 10.1080/00288306.1997.9514777

MatsudA, I. \& IsOZAKI, Y. 1991. Well documentd travel history of Mesozoic pelagic chert in Japan from remote ocean to subduction zone. Tectonics 10, 475-499. DOI 10.1029/90TC02134

McCarthy, A.J., Jasin, B. \& Haile, N.S. 2001. Middle Jurassic radiolarian chert, Indarung, Padang District, and its implications for the tectonic evolution of western Sumatra, Indonesia. Journal of Asian Earth Sciences 19, 31-44. DOI 10.1016/S1367-9120(00)00009-2

MizutANI, S. \& Kido, S. 1983. Radiolarians in Middle Jurassic siliceous shale from Kamiaso, Gifu Prefecture, central Japan. Transactions and Proceedings of the Palaeontological Society of Japan, N.S. 132, 253-262.

Mizutani, S. \& KoJima, S. 1992. Mesozoic radiolarian biostratigraphy of Japan and collage tectonics along the eastern continental margin of Asia. Palaeogeography, Palaeoclimatology, Palaeoecology 96, 3-22. DOI 10.1016/0031-0182(92)90056-B

Mizutani, S., Kojima, S., ShaO, J.A. \& Zhang, Q.L. 1986. Mesozoic radiolarians from the Nadanhada Area, Northeast China. Proceedings of the Japan Academy of Science, Series B, 327-340.

Mizutani, S., Shao, J. \& Zhang, Q. 1990. The Nadanhada Terrane in relation to Mesozoic tectonics on continental margins of East Asia. Acta Geologica Sinica 3, 15-29.

Montgomery, H. \& KerR, A.C. 2009. Rethinking the origins of the red chert of La Désirade, French West Indies. Geological Society of London, Special Publication 328, 457-467. DOI 10.1144/SP328.18

Montgomery, H. \& Pessagno, E.A., Jr. 1994. Paleogeography of Jurassic fragments in the Caribbean. Tectonics 13, 725-732. DOI 10.1029/94TC00455

Montgomery, H., Pessagno, E.A., JR. \& MuÑoz, I.M. 1992. Jurassic (Tithonian) Radiolaria from La Désirade (Lesser Antilles): Preliminary paleontological and tectonic implications. Tectonics 11, 1426-1437. DOI 10.1029/92TC01326
Muller, S.W. \& Ferguson, H.G. 1939. Mesozoic stratigraphy of the Hawthorne and Tonopah Quadrangles, Nevada. Geological Society of America Bulletin 50, 1573-1624.

DOI 10.1130/GSAB-50-1573

Nestell, M.K. \& Stevens, C.H. 2013. Mixed Tethyan and McCloud Belt rugose corals and fusulinids in an Upper Triassic conglomerate, Central Oregon. Journal of Paleontology 87, 909-921. DOI 10.1666/12-138

Orchard, M.J., Cordey, F., Rui, L., Bamber, L.W., Mamet, B., Struik, L.C., SANo, H. \& TAYLOR, H.J. 2001. Biostratigraphic and biogeographic constraints on the Carboniferous to Jurassic Cache Creek terrane in central British Columbia. Canadian Journal of Earth Sciences 38, 551-578. DOI 10.1139/e00-120

OrChard, M.J. \& DANNER, W.R. 1991. Paleontology of the Cache Creek Terrane, 169-186. In SMith, P.L. (ed.) A field guide to the paleontology of southwestern Canada. First Canadian Paleontology Conference. University of British Columbia, Vancouver.

Ota, A. \& Isozaki, Y. 2006. Fusuline biotic turnover across the Guadalupian-Lopingian (Middle-Upper Permian) boundary in mid-oceanic carbonate buildups: Biostratigraphy of accreted limestone in Japan. Journal of Asian Earth Sciences 26, 353-368. DOI 10.1016/j.jseaes.2005.04.001

Pessagno, E.A. \& Blome, C.D. 1986. Faunal affinities and tectogenesis of Mesozoic rocks in the Blue Mountains Province of eastern Oregon and western Idaho. U.S. Geological Survey Professional Paper 1435, 65-93.

Pessagno, E.A., Jr., Cantú-Chapa, A., Hull, D.M., Kelldorf, M., Longoria, J.F., Martin, C., Meng, X., Montgomery, H., Fucugauchi, J.U. \& OGG, J.G. 1999. Stratigraphic evidence for Northwest to Southeast tectonic transport of Jurassic Terranes in central Mexico and the Caribbean (Western Cuba), 123-150. In Mann, P. (ed.) Caribbean Basins: Sedimentary Basins of the World 4. Elsevier.

Pessagno, E.A., JR., Finch, W. \& Aвbott, P.L. 1979. Upper Triassic Radiolaria from The San Hipólito Formation, Baja California. Micropaleontology 25, 160-197. DOI $10.2307 / 1485265$

Pessagno, E.A., JR. \& Hull, D.M. 2002. Upper Jurassic (Oxfordian) Radiolaria from the Sula Islands (East Indies): Their taxonomic, biostratigraphic, chronostratigraphic, and paleobiogeographic significance. Micropaleontology 48(3), 229-256.

Pessagno, E.A., JR., Longoria, J.F., MacLeod, N. \& Six, W.M. 1987. Upper Jurassic (Kimmeridgian-Upper Tithonian) Pantanellidae from the Taman Formation, East-Central Mexico: Tectonostratigraphic, Chronostratigraphic, and Phylogenetic implications. Cushman Foundation Special Publication $23,1-51$.

Pessagno, E.A., Jr. \& Martin, C. 2003. Tectonostratigraphic evidence for the origin of the Gulf of Mexico. American Association of Petroleum Geologists Memoir 78, 5-8.

Pessagno, E.A., JR. \& Whalen, P.A. 1982. Lower and Middle Jurassic Radiolaria (multicyrtid Nassellariina) from California, east-central Oregon and the Queen Charlotte Islands, B.C. Micropaleontology 28, 111-169. DOI 10.2307/1485228

Pessagno, E.A., JR., Whalen, P.A. \& Yeh, K.-Y. 1986. Jurassic Nasselleriina (Radiolaria) from North American Geologic Terranes. Bulletins of American Paleontology 91(326), 1-75. 
Ross, C.A. 1985. Permian Fusulinaceans, 167-185. In Scholle, P.A., Peryt, T.M. \& Ulmer-Scholle, D.S. (eds) The Permian of Northern Pangea, volume 1. Springer-Verlag.

SAnderson, G.A. 1966. Presence of Carboniferous in west Sarawak. American Association of Petroleum Geologists Bulletin 50, 578-580.

Scholz, A., Aberhan, M. \& GonZÁlez-León, C.M. 2008. Early Jurassic bivalves of the Antimonio terrane (Sonora, NW Mexico): Taxonomy, biogeography, and paleogeographic implications. Geological Society of America, Special Paper 442, 269-312.

Sey, I.I. \& Kalachova, E.D. 1983. Ob invazhyakh teticheskikh ammonitov $v$ Borealnie Pozdneoorskie Basseini Vostoka SSSR. Mezozoi Sovetskoi Arktiki, 61-72. Nauka, Novosibirsk.

SHI, G.R. 2006. The marine Permian of East and Northeast Asia: an overview of biostratigraphy, palaeobiogeography and palaeogeographical implications. Journal of Asian Earth Sciences 26, 175-206. DOI 10.1016/j.jseaes.2005.11.004

SosNinA, M.N. 1960. Mikrofaunisticheskie zony karbona i permi Sikhote-Alinya. Mezhdunarodnyi geologicheskii kongress, XXI sessiya. Doklady sovetskikh geologov, Problema 6, $65-68$.

SoKolov, S.D. 1990. Exotic complexes (terranes) in the Koryak Highlands. International Geology Review 32, 117-127. DOI 10.1080/00206819009465762

SPÖRLI, K.B. \& AITA, Y. 1988. Field trip guide to Waipapa basement rocks, Kawakawa Bay, Auckland. Geological Society of New Zealand Miscellaneous Publication 39, 1-27.

SPÖRLI, K.B., AitA, Y. \& Gibson, G.W. 1989. Juxtaposition of Tethyan and non-Tethyan Mesozoic radiolarian faunas in melanges, Waipapa terrane, North Island, New Zealand. Geology 17, 753-756.

DOI 10.1130/0091-7613(1989)017<0753:JOTANT>2.3.CO;2

Spörli, K.B., Aita, Y., Hori, R.S. \& TAKemURA, A. 2007b. Results of multidisciplinary studies of the Permian/Triassic ocean floor sequence (Waipapa Terrane), at Arrow Rocks, Northland, New Zealand. GNS Science Monograph 24, 219-229.

SPÖRLI, K.B. \& GREgory, M.R. 1980. Significance of Tethyan fusulinid limestones of New Zealand. First International Gondwana Symposium, Wellington, New Zealand, 223-229.

Spörli, K.B., TAkemura, A. \& Hori, R.S. (eds) 2007a. The oceanic Permian/Triassic boundary sequence at Arrow Rocks (Oruatemanu), Northland, New Zealand. GNS Science Monograph 24, 1-229.

Stevens, C.H. 1977. Permian depositional provinces and tectonics, Western United States, 113-135. In Stewart, J.H., Stevens, C.H. \& Fritsche, A.E. (eds) Paleozoic Paleogeography of the Western United States, Pacific Coast Paleogeographic Symposium 1. Pacific Section of the S.E.P.M., Los Angeles.

Stevens, C.H., Davydov, V.I. \& Bradley, D. 1997. Permian Tethyan fusulinina from the Kenai Peninsula, Alaska. Journal of Paleontology 71, 985-999.

Suzuki, N., Kojima, J., Kano, H., Yamakita, S, Misaki, A., Ehirio, M., Оtoh, S., Kurihara, T. \& Aoyama, M. 2005. Permian radiolarian fauna from the chert in the Khabarovsk Complex, Far East Russia, and the age of each lithologic unit in the Khabarovsk Complex. Journal of Paleontology 79, $687-701$.

DOI 10.1666/0022-3360(2005)079[0687:PRFFCI]2.0.CO;2

TAN, D.N.K. 1978. Lower Cretaceous age for the chert in the Lupar Valley, West Sarawak. Warta Geologi 4, 173-176.

Tiknomirova, L.B. 1988. Radiolarians of the Far East. Newsletter Stratigraphy 19, 67-77.

Tilman, S.M., Bialobzheskit, A.D. \& Chekhov, A.D. 1982. Tektonika i istoriya razvitiya Koryakskoi geosinklinalnoi sistemy, 5-30. In Pushcharovskir, Y.M. \& Tilman, S.M. (ed.) Ocherki tektoniki Koriakskogo nagoria. Nauka, Moskva.

TumandA, F.P. 1991. Permian radiolaria from Busuanga Island, Palawan, Philippines. Journal of the Geological Society of the Philippines 49(3), 119-193.

Udchachon, M., Burrett, C., Thassanapak, H., Chonglakmani, C., Campbell, H. \& Feng, Q. 2014. Depositional setting and paleoenvironment of the alatoconchid-bearing Middle Permian carbonate ramp sequence in the Indochina Terrane. Journal of Asian Earth Sciences 87, 37-55.

DOI 10.1016/j.jseaes.2014.02.012

Uııѓ, H. \& Ова, T. 1991. Geology and Permo-Jurassic Radiolaria of the Iheya Zone, innermost belt of the Okinawa Islands region, middle Ryukyu Island Arc, Japan. Bulletin of the College of Science, University of the Ryukus 52, 53-89.

VisHNEVSKAYA, V.S. 1992. Significance of Mesozoic radiolarians for tectonostratigraphy in Pacific rim terranes of the former USSR. Palaeogeography, Palaeoclimatology, Palaeoecology 96, 23-39. DOI 10.1016/0031-0182(92)90057-C

VISHNEVSKAYA, V.S. 1994. The Permian radiolarians of Northeastern Russia. Stratigraphy and Geological Correlation 2(4), 359-364.

Vishnevskaya, V.S. \& Filatova, N. 1994. Mesozoic terranes of the northwest Pacific continental margin (Russia): Radiolarian ages and sedimentary environments. The Island Arc 3, 199-220. DOI 10.1111/j.1440-1738.1994.tb00107.x

Vishnevskaya, V.S., Filatova, N.I. \& Dvoryankin, A.I. 1991. Novye dannye o Oorskikh otlozheniniyakh Gori Semiglavoi (Koryakskoe Nagore). Izvestiya Akademii nauk SSSR, Seriya geologicheskaya 4, 21-30.

WAKITA, K. 2000. Cretaceous accretionary-collision complexes in central Indonesia. Journal of Asian Earth Sciences 18, 739-749. DOI 10.1016/S1367-9120(00)00020-1

Wakita, K., Kojima, S. \& Tsukada, K. 2001. Middle Mesozoic accretionary complex of the Mino Terrane, and Paleozoic to Mesozoic sedimentary rocks of the Hida Marginal Belt. ISRGA Field Workshop (FW-C1), 165-235.

Wakita, K. \& Metcalfe, I. 2005. Ocean plate stratigraphy in East and Southeast Asia. Journal of Asian Earth Sciences 24, 679-702. DOI 10.1016/j.jseaes.2004.04.004

Wakita, K., Miyazaki, K., Zulkarnain, I., Sopaheluwakan, J. \& SANyoto, P. 1998. Tectonic implications of new age data for the Meratus Complex of south Kalimantan, Indonesia. The Island Arc 7, 202-222. DOI 10.1046/j.1440-1738.1998.00163.x

WAKITA, K., MunASRI \& BAMBANG, W. 1994. Cretaceous radiolarians from the Luk-Ulo Melange Complex in the Karangsambung area, central Java, Indonesia. Journal of Southeast Asian Earth Sciences 9, 29-41. DOI 10.1016/0743-9547(94)90063-9

Wakita, K., Munasri, Sopaheluwakan, J., Zulkarnain, I. \& MiYAZAKI, K. 1994. Early Cretaceous tectonic events implied 
in the time-lag between the age of radiolarian chert and its metamorphic basement in the Bantimala area, South Sulawesi, Indonesia. The Island Arc 3, 90-102. DOI 10.1111/j.1440-1738.1994.tb00097.x

Whalen, P. \& CARTER, E.S. 2002. Pliensbachian (Lower Jurassic) radiolarians from Baja California Sur, Mexico. Micropaleontology, Supplement 1, 87-151.

Whalen, P.A. \& Pessagno, E.A., JR. 1984. Lower Jurassic Radiolaria, San Hipolito Formation, Vizcaino Peninsula, Baja California Sur. Geology of the Baja California Peninsula, Pacific Section of the S.E.P.M. 39, 53-65.

YANCEY, T.E. 1979. Permian positions of the Northern Hemisphere continents as determined from marine biotic provinces, 239-247. In Gray, J. \& Boucot, A.J. (eds) Historical Biogeography, Plate Tectonics and the Changing Environment. Oregon State University Press.

YANG, Q. \& MizUTANI, S. 1991. Radiolaria from the Nadanhada Terrane, Northeast China. Journal of Earth Sciences, Nagoya University 38, 49-78.

YAO, A. 1982. Middle Triassic to Early Jurassic radiolarians from the Inuyama Area, Central Japan. Journal of Geosciences, Osaka City University 23(4), 53-70.

YAO, A. 1983. Paleozoic and Mesozoic radiolarians from Southwest Japan, 361-376. In IsimA, A. et al. (eds) Siliceous deposits in the Pacific region. Elsevier.
Yao, A., Matsuda, T. \& Isozaki, Y. 1980. Triassic and Jurassic radiolarians from the Inuyama Area, Central Japan. Journal of Geosciences, Osaka City University 23(4), 135-154.

YeH, K.-Y. \& YANG, Q. 2006. Radiolarian assemblages from T-J boundary strata, Nadanhada Terrane, NE China. Acta Micropalaeontographica Sinica 23, 317-360.

Zamoras, L.R. \& Matsuoka, A. 2000. Early Late Jurassic radiolarians from the clastic unit in Busuanga Island, North Palawan, Philippines. Science Reports of Niigata University, Series E (Geology) 15, 91-109.

Zamoras, L.R. \& MatsuokA, A. 2001. Malampaya Sound Group: a Jurassic-early Cretaceous accretionary complex in Busuanga Island, North Palawan Block (Philippines). Journal of the Geological Society of Japan 107, 316-336. DOI 10.5575/geosoc.107.316

Zhang, Q.-N. 1990. Triassic and Jurassic Radiolaria fauna in Nadanhada Range, Northeast China. Shenyang di Zhi kuang chan yan jiu suo suio kan (Bulletin of the Shenyang Institute of Geology and Mineral Resources, Chinese Academy of Geological Sciences) 21, 157-191.

Zyabrev, S. \& Matsuoka, A. 1999. Late Jurassic (Tithonian) radiolarians from a clastic unit of the Khabarovsk Complex (Russian Far East): Significance for subduction accretion timing and terrane correlation. The Island Arc 8, 30-37. DOI 10.1046/j.1440-1738.1999.00220.x 